\title{
Sultan Abdülaziz Dönemi Balkanlar'ına İmgesel Bir Bakış: Balkanlaşma Kavramının Ortaya Çıkışına Dair Bir Önerme
}

\author{
Galip Çă̆ ${ }^{*}$
}

(ORCID ID: 0000-0001-8170-6053)

\author{
Makale Gönderim Tarihi \\ 24.01.2020
}

\author{
Makale Kabul Tarihi \\ 20.02.2020
}

\section{Özet}

Osmanlı idaresinin özellikle 19. yüzyılda bölgede zayıflaması ile Balkanlar yeniden bir inşa sürecine sokuldu. Yeni kavramlar, yeni sınırlar ve yeni tanımlamalar ile sadece Osmanlı sonrası için değil Osmanlı öncesine dair de yeni bir tarih yazılmaya çalışıldı. Şüphesiz bunda kıta Avrupası'nın Osmanlı geçmişine bağlı ötekileştirmeleri önemli rol oynadı.

19. yüzyıl sonları ile birlikte bahsi geçen yeni inşa süreci kendini iyice belli ederken tüm bu süreç Balkanizasyon adı verilen yeni bir düşünce tarzına evrildi. Tarih, edebiyat, sosyoloji ve diğer birçok bilim dalı bu manipülasyon için seferber edildi. Yeni ürünler kendini belli ettikçe Balkanlar Avrupa'nın ötekisi haline getirildi. Ve bu süreç hiçbir zaman da nihayete ermedi.

Balkanizasyon sürecinin ne zaman başladığı ve kökenleri net bir şekilde belirlenememekle birlikte kabaca 19. yüzyıl ortalarında belirginleşen noktaları olduğu açıktır. Konuya dair batıda giderek artan çalışmalar olmakla birlikte Türkiye'de bu süreç yavaş işlemekte. Bu çalışma da Balkanizasyon'un kökenlerine dair bir öneri niyeti ile kaleme alındı. Sultan Abdülaziz dönemine dair bir değerlendirme ile şekillenecek çalışma ile Balkanizasyon fikrinin ortaya çıkışı aydınlatılmaya çalışılacaktır.

Anahtar Kelimeler: Abdülaziz, Osmanlı, Balkanizasyon, Avrupa, Balkanlar.

\footnotetext{
* Dr. Öğr. Üyesi, Abant İzzet Baysal Üniversitesi, Fen-Edebiyat Fakültesi, Tarih Bölümü, galipcag@gmail.com.
}

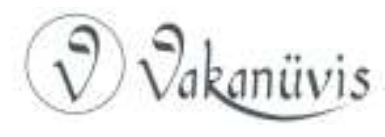




\title{
An Imaginative Look at the Balkans of the Sultan Abdulaziz Period: A Proposal on the Appearance of the Balkanization Concept
}

\begin{abstract}
With the weakening of the Ottoman administration in the region, the Balkans was re-entered into a building process. With new concepts, new borders and new definitions, a new history was tried to be written not only for the post-Ottoman period but also for the pre-Ottoman period. Undoubtedly, the marginalization of continental Europe on the Ottoman past played an important role.

With the end of the 19th century, the new construction process evolved and the whole process evolved into a new way of thinking called Balkanization. History, literature, sociology and many other disciplines were mobilized for this manipulation. As new products became apparent, the Balkans became the other Europe. And this process has never come to an end.

It is clear that when the Balkanization process began and the origins of which have not been clearly identified, there are points that have become roughly apparent in the mid-19th century. Although studies on the subject in the West increasingly slow process in this process in Turkey. This study was written with the intention of suggesting the origins of Balkanization. The study will be shaped by an evaluation of Sultan Abdülaziz period and the emergence of the idea of Balkanization will be tried to be clarified.

Keywords: Abdülaziz, Ottoman, Balkanization, Europe, Balkans.

\section{Giriş}

Son yıllarda Balkanlar'a dair tarihi ve siyasi değerlendirmelerde sıklıkla atıflar yapılan Balkanlaşma (Balkanizm) kavramı artık farklı yönleri ile analiz edilen bir olgu. Bilhassa öteki'nin siyasi literatürde sıklıkla dile getirilmeye başlanması ile Avrupa/Batı ve Doğu arasında bir özel alan, bir ıssız ada, bir marjinal saha şeklinde lanse edilen Balkan coğrafyasının durumu bu kavramla iyiden iyiye bir çıkmaza girmiştir. Bugünün dünyası özellikle küreselleşen düzende biraz da modern emperyal bir tavırla bahsi geçen ayrık durumu gidermeye çalışsa da ön yargılar ve saptırılmış olgularla yönlenen algıların değişmesi şüphesiz ki kolay olamamaktadır.
\end{abstract}

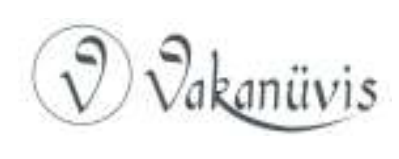


Bahsi geçen arızalı durumun giderilmesi, de facto durum göz önüne alındığında imkânsız gibi görünse de modernler açısından mühim bir uğraştır. Bu uğraşın en can alıcı noktası; ortaya çıkışı ya da bu çıkışı doğuran şartlardır. Bugüne dek kavramın ortaya çıkışı genel anlamda Balkan Savaşları'nın hemen sonrasına tarihlense de (Carnegie Vakfı Raporu ${ }^{1 \prime n}$ un da etkisi ile) aslında düşünülenin ötesinde bir süreç gözden kaçmaktadır.

Özellikle Osmanlı idaresinin bölgede sağladığı hâkimiyet ile birlikte coğrafya adeta kendi içine kapatılırken ve o güne dek Avrupa'nın bitim ucu olan alan lanetli bir bölgeye dönüştürüldü. Bu andan itibaren gerek yerel kültür unsurları gerekse de resmi yazın kültürü Türk-İslamOsmanlı ortak kavramına karşı bir savunma ve buna paralel bir karalama propagandasına başladı. Dolayısıyla Balkanistik algının temel argümanlarının Balkan Savaşları'nın oluşturduğu yeni konjonktürde aranması mevzunun analizinin doğru yapılmasını engeller en azından eksik bırakır durumdadır.

Bu çalışma özellikle, 19. yüzyılın Osmanlı Devleti için en kritik sürecinin hemen öncesinde, 15 yıllık bir periyotta öncelikle Batı medya ve yazın kültüründe Balkanizm'e argüman olacak yaklaşımları inceleyecek, akabinde düşüncenin ortaya çıkışına dair yeni bir tarihlendirmeyi bu döneme eşleyerek ortaya koymaya çalışacaktır.

\section{Sultan Abdülaziz ve Balkan Coğrafyasında Kaynayan Kazan}

Sultan Abdülaziz'in iktidar dönemi başa geçtiği ilk andan itibaren oldukça çalkantılı bir seyir izlerken; $O$ bu süreçte hem kişiliği hem de eylemleri ile sadece Osmanlı tarihine değil dünya tarihine de ciddi tesirlerde bulundu. Osmanlı tarihinin III. Selim ile başlayan pratikte en yoğun Batılılaşma sürecinin adeta kilit noktasında, babasının başlattığı süreci oldukça emin şekilde yürüten ağabeyinin yerine 25 Haziran 1861 'de geçen Abdülaziz süreci belirli ölçüde devam ettirirken gerek karakter özellikleri gerekse de geleneksel düzenin aksine uygulamaları ile kendine Osmanlı modernleşmesinde farklı yer edindi. Halifeliğin

\footnotetext{
${ }^{1}$ Rapora dair ayrıntılı bilgi için bkz., Galip Çağ, "Balkan Savaşlarına Uluslararası Bir Bakış: 1914 Carnegie Vakfi Raporu”, I. Uluslar arası Balkan Kongresi 24-26 Eylül 2012, İstanbul, 2012 ss. 1409-1422.
}

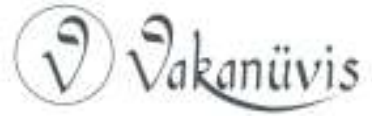


Osmanlı'ya geçişinden sonra ilk ve son kez Mısır'ı ziyaret eden Abdülaziz'in bu hareketi birçokları tarafında fıtri özelliklerinin I. Selim ile eşleşmesinin de önünü açtı ${ }^{2}$. Bunun yanında İslam Dünyası'nın gözünde hanedan yeni bir yükseliş sürecine girdi.

Abdülaziz' in devrinde gerçekleştirdiği bir diğer mühim hareket de Batı Avrupa gezisi oldu şüphesiz. Zira bir Osmanlı padişahının ilk kez gerçekleştirdiği bu ziyaret Avrupa'da mühim bir ses getirirken Batı dünyasının Osmanlı padişahına gösterdiği ilgi de oldukça şaşırtıcıdır. Ancak Abdülaziz'in seyahatine salt bir siyasi gezi, münferit bir hadise şeklinde yaklaşmak seyahati zorunlu kılan saiklerin doğru görülememesine sebep olabileceği gibi seyahate yüklenen manaları da eksik kılacaktır. Bu manada öncelikle Abdülaziz'in tahta geçişinden seyahate çıktığı 1867 yılının 21 Haziran'ına kadar ki sürede Balkanlar'da yaşananlara bakmak ve dahi seyahati bu durumla eşleştirmek doğru bir girişim olacaktır.

\section{Sultan Abdülaziz'in illk Döneminde (1861-1868) Balkanlar'da Anarşi}

19. yüzyıla gelindiğinde Avrupa'nın güneydoğu ucundaki halkların sakin ve huzurlu hayatları bölge düşünürlerini etkilemeye başlayan çağdaş iki yeni düşünce ile yeniden yapılandırılmaya başlandı: Liberalizm ve romantik nasyonalizm. Barbara Jelavich'e göre bu etkileşimin temelinde Balkan milliyetçilerinin doğa bilimlerinde var olan tabiat kanunlarının benzerlerinin bahsi geçen düşünce modelleri ile siyaset ve devlet yapılarına uygulanabileceğine olan inançları yatıyordu ${ }^{3}$. Bu durum da bir nevi sosyal darwinizm bakışı doğurdu ki bu yüzyıın başında ortaya çıkan ulusçu hareketlerin temelinde yatan algı da bu oldu.

Aslında birbirine zıt olan iki düşünce yapısının; liberalizm ve milliyetçiliğin 19. yüzyılda neşv'ü nema bulduğu ortak nokta açıkça belli idi: Osmanlı ve Habsburg hanedanlıklarının yıkılarak yerlerine

\footnotetext{
2 Bu seyahat ile ilgili olarak bkz., Sümeyra Durak, "Sultan Abdülaziz'in Mısır Seyahatine Dair Bir Kaynak Kitap “Voyage Du Sultan Abdulaziz de Stambul au Caire”, Milli Saraylar Dergisi, Sayı: 7, İstanbul, 2011, ss. 175-187.

3 Barbara Jelavich, Balkan Tarihi I, Çev. İ. Durdu, H. Koç, G. Koç, Küre Yay., İstanbul 2009, s. 195-196.
}

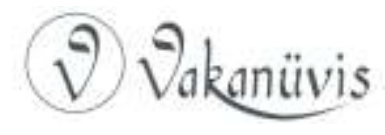


anayasal ulus devletlerinin kurulması. Bu noktadan bakıldığında Güneydoğu Avrupa'nın modern Batı Avrupa için bir tehdit haline gelişinin mazisini 19 . yüzyıl hatta 18 . yüzyıl sonlarına çekmek mümkündür.

Bu çalışmanın konusu itibari ile Balkanlar'da ulusçu hareketleri bir bütün olarak ele almaktansa tarihi sınırları göz önüne alarak Abdülaziz dönemine gelmekte fayda vardır. Abdülaziz'in başa geçtiği 1861'e gelindiğinde Balkan coğrafyası kendi üzerinde stratejiler kurmaya çalışan iki önemli devlet ile karşı karşıya idi: Avusturya ve Rusya. Avusturya bu tarihler itibari ile yakın zamanda italya ve Almanya'ya karşı kaybettiği Orta ve Güney Avrupa hâkimiyetini yeniden kazanma yolunda hamlelere hazırlanırken diğer yandan da olası bir Balkan toprak bütünlüğüne sebep olduğunda oluşabilecek Slav nüfus birliğinin tehditkâr duruşundan çekiniyordu ${ }^{4}$. Zira bu durumda Rusya'nın, bölgeye karşı girişeceği bir hâkimiyet hareketinde tüm Slavları bir anda etkilemesi olası bir durumdu. Kaldı ki hemen hemen aynı anda patlayan ve devam eden Karadağ, Eflak, Boğdan, Sırp, Girit, Bulgar ve Hersek İsyanları bahsi geçen karmaşanın artık bölge için yeni bir yapılanmayı kaçınılmaz kıldığını, fail ile mefulün ciddi bir girift durum ortaya koyduğunu ispatlamaktadır.

Öte taraftan III. Napolyon'un milli prensip (le principe de nationalité $)^{5}$ savunucusu olması ve Balkanlar'daki bağımsızlık hareketlerini desteklemesi de önemlidir. Fransa'nın şark siyaseti 1861 güzünde önemli bir değişime uğradı. Zira önceki yıllarda Fransa Balkanlar'da Osmanlı karşıtı herhangi bir isyan hareketine hep karşı dururken Ekim-Kasım 1861'de Fransa dış işleri bakanı ilk defa Sırbistan, Eflak, Boğdan, Karadağ ve Yunanistan'ın Osmanlı'ya karşı ortak bir harekâtına sempatiyle yaklaşacaklarını ifade etti. Bu dönüşüm şüphesiz ki Balkan halklarının Osmanlı'ya karşı giriştikleri ayrılıkçı eylemlerine destek vermek noktasında idi. Napolyon bu ayaklanmaların kendisinin

\footnotetext{
${ }^{4}$ Mithat Aydın, "Osmanlı-Sırp, Karadağ Savaşlarında İngiltere'nin Balkan Politikası", OTAM , Sayı:15, Ankara, 2004, s. 141.

${ }^{5}$ Hukukta birçok manada kullanılmakla birlikte "burada bir devletin egemenliği altında bulunan bağımsız, uluslararası antlaşmalara dayalı sınırlarla çevrili, üzerinde dil, kültür ve ülkü bakımından birlik oluşturan bir ulusun yaşadığı toprakların tümü" yerine kullanılmıştır.
}

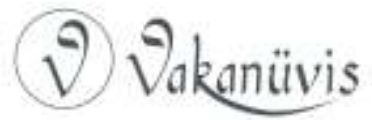


İtalya üzerindeki siyasi planlarına yardım edeceğini düşünmekteydi. Böyle bir ayaklanmada Bosna-Hersek Avusturya'ya italya ile birleşen Venedik karşılığında bir telafi olarak verilebilirdi. Böylelikle hem Avusturyalı emperyalistler hem de İtalyan milliyetçiler tatmin olacak, kendisi de Avrupa işlerinde başat bir rol üstlenecekti ${ }^{6}$.

1861 ile 1864 yılları arasında gerçekleşen Karadağ İsyanları, Batı Avrupa'nın Doğu Sorunu ve dahi Balkanlar'ın 19. yüzyıl başındaki ilk liberal ve romantik milliyetçi hareketliliği sonrasındaki düzen arayışının mühim bir kırılma noktası oldu. 1856 yılından önce daha Viyana'da (1815) dile getirilmeye başlanan Balkanlar üzerinden yeni bir Avrupa coğrafik düzeni çabası 1856 yılı sonrasında eyleme döküldü ve ilk meyveler bahsi geçen isyanlar vesilesi ile alınmaya başlandı. Yeni düzenlemenin ev sahibi Osmanlı idaresinin içine düştüğü karmaşa onun dahi coğrafyaya bakışını etkilemeye başladı. Dönemin sadrazamlarından Fuad Paşa dahi çağdaşı Marx'ın "etnik süprüntü" dediği bölgeyi "dünya barışını tehdit eden anlamsız devletçikler" şeklinde tanımlamakta bir beis görmedi". Karadağ İsyanları'nın başlangıcı da bu düşüncenin temellerini oluşturacak bir öncülü karşıladı. 1860'da Sırp milliyetçiliğinin babalarından Vuk Karaciç'in, yeni Kral Mihail tarafından Karadağ Prensi Nikola'ya sözde taht değişikliğini tebliğ için gönderilmesi ile birlikte başlayan süreç SırpHersek-Karadağ ortak isyanını da tetikledi ${ }^{8}$. Şimdi Osmanlı topraklarını da içine alan bir alanda mühim bir karmaşa vardı ve bu karmaşanın tam ortasında Avusturya, Fransa ve Rusya duruyordu. Batı ise zaten gözden çıkardığı bu kangrenli uzvunun içine düştüğü durumu politikalarına uygun bir argüman olarak kullanmayı tercih etti ve bölge gittikçe modern Avrupa'nın karanlık bir köşesi haline gelmeye devam etti.

Abdülaziz devrinin belki de en mühim hadisesi dünyanın dengesini büyük ölçüde değiştirecek olan Süveyş Kanalı'nın açılmasıdır. Hidiv

\footnotetext{
6 Selim Arslantaş, "I. Balkan İttifakı (1866-1868)", Ankara Üniversitesi Dil ve TarihCoğrafya Fakültesi Dergisi Cilt: 52, Sayı: 2 Ankara, 2012, s. 3.

7 Erkan Tural, "1861 Hersek İsyanı, 1863 Eyalet Teftişleri ve 1864 Vilayet Nizamnâmesi", Çağdaş Yerel Yönetimler, Cilt 13, Sayı 2, Nisan 2004, s. 93.

${ }^{8}$ Ayşe Özkan, Miloş'tan Milan'a Sırp Bağımsızı̆̆ı (1830-1878), IQ Yay., İstanbul 2011, s. 163.
}

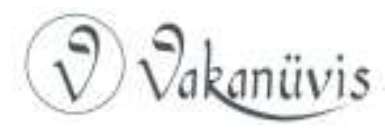


İsmail Paşa önderliğinde Kanal'ın açılması Mısır ile Osmanlı́nın bağını tamamen koparırken ${ }^{9}$ Ortadoğu'da etkinliğini arttıran İngilizlerin, ana karası ile arasında bulunan Osmanlı'nın akıbetini Balkanlar üzerinden yeniden kurgulaması kadar doğal bir şey yoktu. Ancak Osmanlı Devleti'nin topyekûn ve bir anda çöküşünün hâlihazırda kontrol edilmekte zorlanılan bu bölgede çok daha vahim bir kara deliğe sebep olabileceği kaygısı aceleci davranmayı öteliyordu. Tabii bölgede değişen konjonktür göz önüne alındığında yoğunlaşan oryantalist ilgi de dikkat çekiyordu ${ }^{10}$. Özellikle İngiliz ve Fransız seyyahların (Sadler, Palgrave, Philby v.d.) seyahatleri coğrafyanın ne kadar ciddi bir odak olduğunu gösterirken bu seyahatlerin bir kısmının gizli tutulması da Doğu Sorunu'nun Batı Avrupa için ehemmiyetini ortaya koyuyordu ${ }^{11}$. Bu durumda Osmanlı'yı ortadan kaldırmaktansa küçük parçalara ayırıp bu parçacıkları da mazilerinden uzak bir istikbale aslında var olmayan bir geçmiş örüntüsü ile taşımak makul bir çözüm gibi göründü. Bu da Karadağ olayları ile eş zamanlı diğer ayaklanmaları peşi sıra getirdi.

Kırım Harbi sonrasında Batı'nın Osmanlı toprak bütünlüğünü garanti edişinin üzerinden çok geçmeden peşi sıra patlak veren Balkan isyanları, Paris'te gerçekleşen görüşmelerin ve verilen teminatların ne kadar (samimi!) olduğunu tüm dünyaya gösterdi. Karadağ ile birlikte eşzamanlı olarak başlayan ve 1866 'ya kadar devam eden Memleketeyn (Eflak-Boğdan) isyanları da bu sürecin etkin hadiselerinden biridir.

1859'da Eflak ve Boğdan reisi seçilen Alexandru İon Cuza daha sonra Abdülaziz ile yaptığı iki görüşme sonunda Memleketeyn Prensi tanındığında ${ }^{12}$ problemler büyük ölçüde çözülmüş gibi göründü. Romanya kurulmuş, dahası bu durum bizzat Abdülaziz tarafından da tasdiklenmişti. Castellan'a göre Balkanlar'a kapitalizmin girişi de tam da bu zamanlara tesadüf eder ${ }^{13}$. Zira Paris Anlaşması'nın 1856'da

9 Donald Quataert, Osmanlı Imparatorluğu 1700-1922, Çev. Ayşe Berktay, Iletişim Yay., İstanbul 2004, s. 101.

10 Emine Sarıkoyuncu Değerli, “ingiltere'nin Doğu (Şark) Politikası (1882-1914)”, Akademik Bakış, Sayı:14, Nisan, Ankara, 2008, s. 3

11 V.V. Barthold, Rusya ve Avrupa'da Oryantalizm, Terc. Kaya Bayraktar, Ayşe Meral, Küre Yay., İstanbul,2004, s. 223.

12 Aurel Decei, "Eflak" maddesi, IA, Milli Eğitim Basımevi, İstanbul, 1978, s. 188.

${ }^{13}$ Georges Castellan, Balkanların Tarihi, Çev. Ayşegül Yaraman Başbuğu, Milliyet Yay., İstanbul, 1993, s. 354.

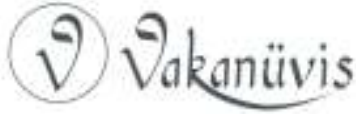


Karadeniz'i uluslararası bir ticaret alanı haline getirişi Balkanlar'ı da doğal bir pazar haline getirdi. Bu durumda sadece Ortadoğu gelişmeleri değil bunun yanında bu ticari hamlenin de bölgenin Avrupa için farklı bir noktaya kaymasını kaçınılmaz kıldı. Cuza'nın reisliğinden Carol'un başa geçtiği 1866'ya kadar ki dönemde Romanya'da yaşananlar bölgede arananın Osmanlı sonrası anayasal düzene bağlı yeni yapılar değil emperyalizm eşiğindeki anakaranın "Osmanlı karanlığında kalan" bitim ucuna dair yeni bir düzenleme gayreti olduğunu gösterdi.

Sultan Abdülaziz döneminde Sırp meselesi oldukça ciddi bir dönüşümle başladı. Miloş Obrenoviç'in ölümü sonrasında Belgrad Muhafızı Şerif Osman'ın Bab-ı Âli adına tasdik ve tebriği ile Sırp knezi olan Mihail Obrenoviç başa geçtiği andan itibaren ana düşünce olarak Sırpları bağımsızlıklarına kavuşturmayı planladı. Bunun için şüphesiz ki Avrupa'dan destek almalıydı. 1860'da Yovan Marinoviç'i de bu sebeple görevlendirerek Avrupa'ya gönderdi ${ }^{14}$. Viyana, Paris, Petersburg ve Berlin'deki temaslarında Marinoviç özellikle Rusya'dan destek görürken diğer devletler halen temkinliydiler.

Sırplar bu süreçte kendileri gibi kaynamaya hazır diğer Balkan toplulukları ile de temasa geçtiler. Özellikle Karadağ'dan gördükleri destek ve hemen sonrasında Hersek'te başlayan ayaklanma Osmanlı idaresini ciddi sıkıntıya düşürdü. Bu arada bölgede bulunan Fransız, Rus ve Avusturyalı murahhasların isyanları kışkırtıcı tavrı meselenin derinliğini arttırdı. Hatta öyle bir durum ortaya çıktı ki çok da uzak olmayan bir geçmişte Osmanlı uc bölgesi olan Sırp topraklarında "Türklere karşı savaşmak bir eğlence yada bir tür açık hava sporu olarak" görülüyordu ${ }^{15}$.

$\mathrm{Bu}$ arada ayaklanmaların artması ile birlikte sadece Balkan halklarının imajı tehlikeye girmedi bunun yanında Osmanlı idaresinin Balkanlılara karşı tavırları ile alakalı da bir takım spekülasyonlar ilk kez Batı literatüründe yer buldu. Özellikle isyanların bastırılmasına dair Osmanlı uygulamaları oldukça ayrıntılı bir şekilde anlatılmaya ve

\footnotetext{
14 Özkan, a.g.e., s. 162.

15 Alan Palmer, Son Üç Yüz Yıl Osmanlı Imparatorluğu(Bir Çöküşün Tarihi), Çev. Belkıs Çorakçı Dişbudak, İ̧̧ Bankası Yay., İstanbul, 2003, s. 141.
}

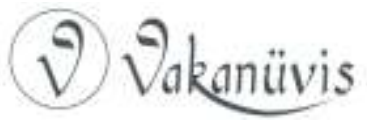


resmedilmeye başlandı. Abdülaziz döneminde Osmanlı askerlerinin asilerin baş, burun ve kulaklarını keserek bunları teşhir ettiğini ifade eden, hatta bununla alakalı tasvirler kaleme alanlar az değildi ${ }^{16}$.

Sultan Abdülaziz'in döneminin ilk çeyreğinde Balkanlar ve Ortadoğu'da yaşananları Avrupa anakarasının Osmanlı sonrası döneme hazırlandığı şeklinde yorumlamak mümkündür. Zira henüz $A B D^{\prime}$ nin dahil olamadığı kapitalist düzenin emperyal bir sürece dönüştüğü tam da bu zamanda Karadeniz ve Doğu Akdeniz ticaretinin bir hakimiyet sahası haline gelişi, Osmanlı uc bölgelerinin olduğundan farklı bir düzenle idaresini kaçınılmaz kılıyordu. Bu süreçte Batı dünyası o güne dek Viyana ve Paris'teki görüşmelere bağlı olarak devam ettirdiği statükocu tavrından da Osmanlı aleyhine bir takım tavizler vermeyi çok da mahsurlu görmedi. Olayların bu düzende geliştiği noktada Osmanlı tarihinde bir ilk olarak Sultan Abdülaziz'in Batı Avrupa seyahati gerçekleşti.

\section{Modern Avrupa'da Tipik Bir Türk ya da Osmanlı Büyük Turu ${ }^{17}$}

Sultan Abdülaziz'in hâkimiyet döneminin ilk beş senesinde Balkanlar'da yaşanan ayrılıkçı hareketler Ortadoğu ve Doğu Akdeniz'deki gelişmelerle iyice içinden çıkılmaz bir hale geldi. Bu süreçte devletin kendini muhafaza edebilmesi ve dirliğini sağlayabilmesi için bir dizi önlem alması, dahası bu hareketlerin müsebbibi olarak gördüğü Batı dünyası ile ortak bir noktada buluşması kaçınılmazdı. Uzun asırlar boyunca hâkim kılınan ad hoc diplomasinin de beraberinde getirdiği alışkanlıklar o güne dek bir padişahın bu tarz konuları bir başka devlet lideri ile aracısız ve kendi topraklarında konuşmasını pek mümkün kılmıyordu. Ancak şartlar oldukça değiştiğinden bahsi geçen uygulamanın kaçınılmaz olduğunu düşünenler de yok değildi.

\footnotetext{
16 Bozidar Jezernik, Vahşi Avrupa, Batı'da Balkan Imajı, Çev. Haşim Koç, Küre Yay., İstanbul, 2006, s.163.

17 Palmer, Abdülaziz'in Batı Avrupa Seyahatini Büyük Tur olarak tanımlarken, The Times'ın Abdülaziz için kullandığı tipik bir Türk gibi görünüyordu ifadesini de vurgular; Palmer a.g.e., s. 146.
}

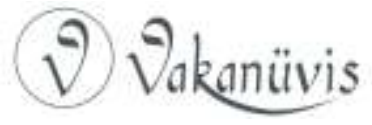


Aslına bakılırsa Abdülaziz'den önce Sultan Abdülmecid'in Batı Avrupa'ya olan ilgisi de dikkat çekicidir. II. Mahmud devri sonrasında Bab-ı Âli'nin yüzünü Avrupa'dan çevirmeyen, öğrendiği Fransızca sayesinde Debas ve illustration gibi gazeteleri takip eden Abdülmecid yabancı elçilerle sık sık görüştü ve müzakerelerde bulundu ${ }^{18}$. Fransa'dan Legion d'honour nişanını kabul ederken, Fransız elçiliğindeki bir baloya da katılmakta mahsur görmedi.

Abdülmecid döneminin yabancı devlet temsilcilerinin ziyaretleri açısından da dikkat çekici olduğu görülür. Fransa veliahdı III. Napolyon, Avusturya İmparatoru'nun kardeşi Arşidük Maximilien, Belçika Kralı'nın iki oğlu ve İngiltere Kraliçesi'nin oğlu bunlardan bazılarıdır. Bu ziyaretler sırasında Prens Napolyon'un Abdülmecid'e yaptığı Fransa daveti aslında Sultan Abdülaziz'in gerçekleştireceği Batı Avrupa seyahatinin de fikri temelini oluşturacaktır ${ }^{19}$.

Abdülmecid'e iletilen bu tekliften 13 yıl sonra Sultan Abdülaziz devrinde büyük bir hareketlilik yaşanıyordu. Bulgarlar ayaklanmış ve yeni bir düzen talepkarı olmuşlarken, son Osmanlı birlikleri Belgrat'ı terk ediyor, bu arada Girit Bunalımı da baş gösteriyordu. Abdülaziz tüm bu karmaşanın çözümünü Osmanlı millet sistemindeki referanslarla kurtulma yolunda ararken 1848 intilalleri'nin yıkıcı etkisi yakasını bırakmıyordu. Statükoyu korumak konusunda Rusya'ya göre daha ılımlı olan Avrupa'nın büyük devletlerinin aksine Rusya ısrarla Hıristiyanlık kozunu oynayarak Osmanlı'nın Hıristiyan Ortodoks tebaasını kışkırtmaya devam ediyordu. Bu noktada Sultan Abdülaziz de bir tercih yaparak Âli ve Fuad Paşaların da teşvikleri ile bu seyahate çıkmayı kabul etti.

21 Haziran 1867 ' de başlayıp 7 Ağustos 1867'de sona eren seyahatin bilhassa Fransa ve İngiltere ayakları dikkat çekicidir. Fransa İmparatoru III. Napolyon'dan, Milletlerarası Paris Sanayi Sergisi'nin açılışı münasebetiyle gelen ilk davet, İngiltere kraliçesinin daveti ile devam etti. Fransa gezisinden hemen sonra Galler Prensi VII. Edward'ın kendisini karşıladığı Londra ziyareti başladı. Burada Kraliçe Victorya ile

\footnotetext{
18 Nihat Karaer, Sultan Abdülaziz'in Avrupa Seyahati ile Osmanlı ve Batı Kamuoyundaki Yankıları, Doktora Tezi, Ankara Üniversitesi, Sosyal Bilimler Enstitüsü, Ankara, 2003, s. 27.

${ }^{19}$ Karaer, a.g.e., s. 30.
}

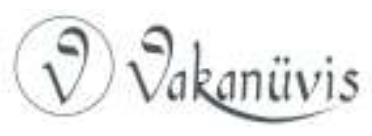


görüştü. Başta tersaneler olmak üzere Londra'nın önemli tarihi ve turistik yerlerini gezen Sultan Abdülaziz on gün sonra Brüksel 'e geçerek kral II. Leopold ile görüştü. Daha sonra Prens Bismarc'ın tavsiyesi üzerine Prusya kralı ve kraliçesi Berlin'e kadar gelerek kendisiyle görüştüler. Aslında Berlin seyahati davetini özürlerini bildirerek kabul edemeyen Sultan Abdülaziz'le görüşülmesini Prens Bismarck Prusya Kralı ve Kraliçesine özellikle tavsiye etti. İstanbul'a dönerken Viyana Garı'nda Avusturya Imparatoru ve Macaristan Kralı tarafından karşılandı. Sonra Budapeşte'ye uğradı ve Vidin yoluyla İstanbul'a döndü ${ }^{20}$. Seyahate kalabalık bir heyet iştirak ediyordu: Veliaht Murad Efendi (V. Murad), Şehzade Abdülhamid Efendi (II. Abdülhamid), padişahın büyük oğlu Yusuf İzzeddin Efendi, kısa süre sonra şeyhülislam olacak olan Hâce-i Sultan Hasan Fehmi Efendi, eski sadrazam Hâriciye Nâzırı Keçecizade Fuad Paşa, Başmabeynci Hüseyin Cemil Bey, Mabeyn Başkâtibi Mehmed Emin Bey, II. Mabeynci Hâfız Mehmed Bey, müstakbel sadrazam Divân-ı Hümâyun Baş Tercümanı Ârifî Bey, Mabeyn İkinci Kâtibi Halîmî Efendi bunlar arasındadır. Yine Fransa Sefîri Mösyö Boure ve İngiltere Sefareti baş tercümanı da davet sahiplerini temsîlen padişahın maiyetinde yer aldılar ${ }^{21}$.

Seyahate nakdi yardım sağlamak, Rusya'ya karşı denge oluşturmak, Balkanlar'daki gelişmelerle alakalı olarak müttefiklerle müzakerelerde bulunmak gibi birçok sebep gösterilirken farklı manalar da yükleyenler yok değildir. Örneğin bu dönemde İstanbul'da yayın yapan La Turquie gazetesi bu seyahatin Batı'daki Türk tutuculuğu ve İslam ile modern arasındaki uyuşmazlığına dair imgesel yanılsamanın giderilmesine katkı sağlayacağını söylüyordu ${ }^{22}$.

Fuar Komiseri Selahattin Bey tarafından yazılan ve Fransızca olarak aynı yıl Paris'te yayınlanan "Türkiye 1867 Evrensel Sergisi" adlı kitapta Selahattin Bey çok daha farklı bir yaklaşımla padişahı 5. Abbasi Halifesi Harun Reşid ile eşler ve İslam medeniyetini Avrupa ile

20 Nejdet Gök, “Mütercim Halîmî Efendi'nin Notları Çerçevesinde Sultan Abdülaziz'in Avrupa Seyahati Ve Sonuçları (21 Haziran 1867 - 7 Ağustos 1867)", Tarihin Peşinde, Sayı: 7, İstanbul, 2012, s. 170.

21 Osman Köksal, "Sultan Aziz'in Avrupa Seyahati Dönüşü Münasebetiyle Yapılan Kutlamalar Ve Bir Manzum Tarihçe", Osmangazi Üniversitesi Sosyal Bilimler Dergisi, Cilt: 4 Sayı: 1 Haziran 2003, s. 119-120.

22 Karaer, a.g.e., s. 46.

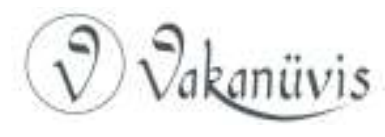


bütünleştirmesine vurgu yapar. Kitabın padişaha takdiminde yazdığı mektupta durumu şöyle ifade eder:

"Majesteleri Sultan Abdül Aziz Han Hazretleri

10 asır evvel, Halife Harun Reşit Hazretleri, Batı Medeniyetlerine arkadaşlık ve dostluk duygularını birer ifadesi olarak dünyada bir numara olan Asya ülkeleri sanayilerinin üretimi neticesinde ortaya çıkan ve dünya çapında söz sahibi olan hediyeleri göndermiştir.

Günümüzde, siz, haşmetmahabları bunu çok daha öteye taşıyarak Fransa Kralı'nın davetine bilfiil kendi icablarınız ile içinde bulunduğumuz zamanın en önemli hadiselerinden biri olan ve katıımımızın davetle elzem olduğu; dünya çapında hayrete mucip olan tarihte altı çizili olarak yer alacak emekçilerin katıımı ve rekabeti ile gerçekleşecek ve bizi takip eden uluslara bir emsal teşkil edecek 1867 l'Exposition Universelle'i teşrif edecektir.

Böylesine büyük hadisenin bir hediyesi olarak, biz haşmetmahablarının naciz kulları olarak işbu eser ile bize yüce efendimizin Pay-i tahtın ilerlemesi ve gelişmesi yönünde açtığı yolda yürüme uğruna ortaya koyduğumuz gayretlerin ve sahip olduğumuz yeteneğin ortaya konulması ve 1863 yılında düzenlenen ve aziz Pay-i tahtın gelecek yolunda ortaya koyduğu kilometre taşı olan 1863 Evrensel Sergisi'nden bu yana kaydedilen inkişafın en iyi şekilde dile getirilmesine çalışılmıştır.

Sadık hizmetkârınız ve kulunuz

Salahaddin

1867 imparatorluk Sergi Komiseri" ${ }^{23 \prime}$

\section{Değişenler, Dönüşenler ve Abdülaziz Devrinde Balkanizm'e Dönüşen Çıkarlar}

Abdülaziz devri, yukarıda da görüldüğü üzere bugüne dek ihmal edilen yönleri ile bir bütün olarak ele alındığında çalışmaya konu olan çerçevede Balkanlar'a dair mühim bir dönüm noktası oldu. 19. yüzyılda Osmanlı lehine tavır alan statükocu Batı Avrupa devletleri Abdülaziz

${ }^{23}$ Bahsi geçen mektup ve kitap için bkz., La Turquie L'exposition Universelle 1867, Exc. Salahheddin Bey, Paris Librairie Hachette, 1867.

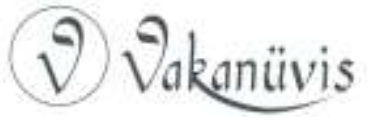


devrine rastgelen Kırım Savaşı sonrası düzende bu tavırlarını değiştirdiler. Yakın zamanlarda Avrupa Birliği müşavirliği yapmış olan Alain Servante bu dönemde yaşanan değişimi şöyle izah eder:

"Türk (Balkan) imajı 19. Yüzyıl başında Byron'un izinde romantik Helenizm hayranlığının patlayışıla Cezayir fethinin sonrasına kadar olumsuzdu; Fransız ve Ingilizlerin Ruslara karşı Türkiye'nin tarafını tuttuğu ve Osmanlı imparatorluğu'ndaki reformların devamını savundukları Kırım Savaşı süresince ise olumlu. Türkiye'nin gerilemesinin, o dönemde Avusturya ve özellikle de emperyalist heveslerin olduğu bilinen Rusya'nın gücüne karşı bir denge unsuru arayışında olan Fransa'nın (ve Ingiltere'nin) çıkarlarına ters düştüğü söylenebilir. Türkiye kendini dönüştürdü ve modernleşti. .....Yüzyllın sonunda Loti ve Claude Farrare'i ve Almanları saymazsak, Türk imajı yine olumsuzdur. Öte yandan Osmanlı Imparatorluğu'ndaki reformlar, özellikle Balkanlar'daki siyasal evrimi dikkate alırsak, fazla gecikmişti. Batı, dinsel ve ulusal azınlıklara sırtını yaslayarak kendi ilkelerini çiğneyerek çıkarlarına göre davrandı. Yönetmek için böldü.

Kendi imgesini gerçek kılan Medusa gibi, Türklerin aynadan yansıyan çarpıtılmış imgesi, değişimlerine ket vurabilir. ${ }^{24 \prime}$

Abdülaziz döneminde son birkaç yılına damga vuran Bulgar ve Hersek İsyanları sırasında bir çok seyyah Balkanlar'da cirit attı. Zira o güne dek ürkütücü kimliği ile Batı dünyası için bir karabasan bir karanlık orman olan Osmanlı Devleti şimdi bir anarşi yatağı idi ve bu durumu görmeli, dahası öğretmeliydiler. 1875'te tüm Bosna'yı yaya gezen Arthur John Evans kıyıma Bosnalılarla başlar ve kendisine brat yani kardeşim şeklinde hitap eden bu sarıklı barbarlardan duyduğu rahatsızlığ büyük bir öfke ile belirtir ${ }^{25}$. Abdülaziz devrinin sonu itibari ile Bosna'ya böyle bakılmaktadır.

Daha da kötüsü Balkan halkları da yavaş yavaş bu bakışa kendilerini alıştırmaya başladılar. Bizzat hükümdarları dahi bu durumla eğlenecek

\footnotetext{
${ }^{24}$ Alain Servante, "Batılıların Gözünde Türk İmajının Geçirdiği Değişimler, Cehennem Teolojisinden Demokrasi Derslerine", Dünyada Türk Imgesi, Çev. Serpil Çağlayan, Yay. Haz. Özlem Kumrular, Kitap Yayınevi, İstanbul, 2005, s.71

25 Arthur John Evans, Through Bosnia and the Herzegovina On Foot During The insurrection, August and September 1875, Londra, 1877, s. 311-12.
}

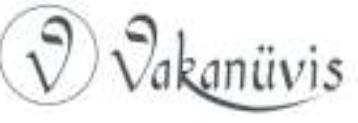


kadar yadsıdı bu durumu. Abdülaziz' in çağdaşı ve dönemin isyanlarında mühim rol oynayan Prens Nikola bir Fransız seyyah ile gerçekleştirdiği sohbette Avrupa'nın gözünde bir mezbahane gibi lanse edilen Karadağ topraklarında gezebilmesini büyük bir cesaret örneği olarak kabul eder ve şu kinayeli konuşmayı yapar:

"(Gülerek) Bilmiyormusunuz; biz çok vahşiyiz, çocuklarımızı dahi yeriz; eğer onları nasıl pişirdiğimizi görmek isterseniz bu akşam saat sekizde yemeğe kalmalısınız. ${ }^{26 "}$

\section{Sonuç}

18. yüzyıl sonunda Avrupa'da monarşik düzene karşı büyük bir tehdit olarak ortaya çıkan ulusçu düşünce, anakarada ciddi bir savunma sisteminin doğal olarak gelişmesini de kaçınılmaz kıldı. Bir taraftan mevcut statü korunmaya çalışılırken diğer yandan muhtemel tehditlerin Batı Avrupa'da bir risk oluşturmasına karşı tercih değişikliklerine gidildi. Yüzyılın ilk yarısına kadar restorasyon devri denilen süreçte eskinin muhafazası konusunda birlik içinde olan Avrupalı devletler Kırım Harbi sonrasında Osmanlı'yı kendi salahiyetleri için feda etmekte bir sıkıntı görmediler. Halihazırda karmaşanın, isyanın ve ayrılıkların var olduğu Güneydoğu Avrupa'da daha sistemli ve topyekün bir kaosun hakim olması da tam bu zamana rasgeldi.

II. Mahmud ve Abdülmecid dönemlerinin modernleşme adı altında devleti muhafaza hamleleri, Osmanlı topraklarında belirli değişim ve dönüşümü beraberinde getirdi. Ancak aynı dönüşüm Balkan toprakları için çok da etkili olmadı. Zira Batı Osmanlııı, Türklük, Müslümanlık ve Balkanlılık kavramlarını çoktan birbiri ile eşlemiş ve buradan hareketle bölgeyi iyiden iyiye bir anarşi merkezi olarak tanımlamıştı. Abdülaziz'in Avrupa seyahati sırasında yabancı basının Türk imajı üzerinden yaptığı yorumlar ve gidilen her yerde gösterilen ilgi bu imajinasyonun doğrulanması niyetinin yarattığı merak duygusundan öte değildi.

Bugün Balkan kimliği ve Balkanlılık tabirleri Avrupa'da gösterdiği gelişmenin de bir sonucu olarak ulusal akademinin dikkatini çekmeye başlayan bir konu. Ancak henüz olgunlaşmadığından ve kaynakları Batı

${ }^{26}$ Jezernik, a.g.e., s. 117.

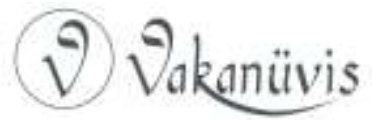


dillerinden aktarılmadığından doğru bir perspektifle bakıldığını söylemek zor.

Tarih sınırları itibari ile oldukça zor bir disiplin. Zaman zaman araştırmacıların işlerini kolaylaştırmak adına sınırlar daha da belirginleştirilse de bu açıdan sürekli eleştirilen ve tartışılan da bir alan. Balkanizm bu tartışma alanında küçük bir başlık. Bugüne dek sınırları çoğunlukla Balkan Savaşları ile başlatıldığından anlaşılmak konusunda da eksik.

Bu çalışmada, Abdülaziz devrinde Balkanlar'da yaşananların Ortadoğu'da yaşananlarla ilintili oluşuna, bunun Avrupa'da Türk'e, Balkanlar'a, İslam'a bakışta değişim ve dönüşümlerine dair veriler sunuldu. Ortaya konan veriler, Balkanlar'ın Avrupa'nın gözündeki imajinal değişiminin Balkan Savaşları'nın öncesinde aranması gerekliliğini doğurdu. Çalışmalar artıkça şüphesiz ki konu farklı menfezler bulacak ve daha da belirginleşecek. Ancak bugün gelinen noktada Sultan Abdülaziz döneminde Süveyş Kanalı'nın açılışı sonrası değişen jeopolitik etki alanı, Ortadoğu'da değişen dengeler, en azından statükonun korunması adına Osmanlı'ya duyulan ihtiyaca binaen Balkanlar'ı sarsacak hareketliliğin yıkıcı etkileri bu düşüncenin zamansal sınırını yüzyılın hemen ikinci yarısına çekmektedir.

Sonuç itibari ile bu çalışma, Balkanistik düşüncenin temellerinin eldeki veriler ve yaşananlar ışı̆̆ında Sultan Abdülaziz devri Osmanlı topraklarında yaşananlarda, padişahın Batı Avrupa gezisinde ve dahi Süveyş Kanalı'nın açılmasında görülmesi gerektiğini iddia etmektedir. Buna, bahsi geçen dönemde Karadeniz'in sömürgeci düşüncenin mühim bir sahası haline getirilmesi sonrasında açık pazara dönüşen Balkanlar'ın Osmanlı bağının tamamen koparılması çabasını da eklemek zaruridir.

Bu manada Balkanlar'ın bugün gelinen noktada doğru bir bakışla tahlil edilebilmesi, Avrupa için Balkanlar, Balkanlar için Avrupa'nın ne ifade ettiğinin doğru anlaşılması için Sultan Abdülaziz dönemi Balkanlarının her açıdan iyi değerlendirilmesi ve imgelerin, algıların doğru bir cihete yönlenmesi adına gözler önüne serilmesi önemli bir gerekliliktir.

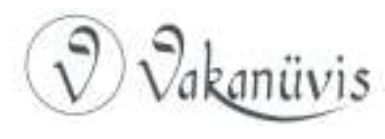




\section{Kaynakça}

Arslantaş, Selim, “I. Balkan İttifakı (1866-1868)”, Ankara Üniversitesi Dil ve Tarih-Coğrafya Fakültesi Dergisi Cilt: 52 Sayı: 2 Ankara, 2012, s. 1-14.

Aydın, Mithat, "Osmanlı-Sırp, Karadağ Savaşlarında İngiltere'nin Balkan Politikası", OTAM, Sayı:15, Ankara, 2004, s. 139-163.

Barthold, V.V., Rusya ve Avrupa'da Oryantalizm, Terc. Kaya Bayraktar, Ayşe Meral, Küre Yay., İstanbul,2004.

Castellan, Georges, Balkanların Tarihi, Çev. Ayşegül Yaraman Başbuğu, Milliyet Yay., İstanbul, 1993.

Çağ, Galip, "Balkan Savaşlarına Uluslararası Bir Bakış: 1914 Carnegie Vakfi Raporu", I. Uluslar arası Balkan Kongresi 24-26 Eylül 2012, Süleyman Şah Üniversitesi., 2012 s. 1409-1422.

Decei, Aurel, Eflak maddesi, IA, Milli Eğitim Basımevi, İstanbul, 1978, s. 178-189.

Değerli, Emine Sarıkoyuncu, “İngiltere'nin Doğu (Şark) Politikası (18821914)", Akademik Bakış, Sayı:14, Nisan, Ankara, 2008, s. 1-15.

Durak, Sümeyra, "Sultan Abdülaziz'in Mısır Seyahatine Dair Bir Kaynak Kitap "Voyage Du Sultan Abdulaziz de Stambul au Caire", Milli Saraylar Dergisi, Sayı: 7, İstanbul, 2011, s. 175-187.

Evans, Arthur John, Through Bosnia and the Herzegovina On Foot During The Insurrection, August and September 1875, Londra, 1877.

Gök, Nejdet, “Mütercim Halîmî Efendi'nin Notları Çerçevesinde Sultan Abdülaziz'in Avrupa Seyahati Ve Sonuçları (21 Haziran 1867 - 7 Ağustos 1867)", Tarihin Peşinde, Sayı: 7, İstanbul, 2012, s. 165-188.

Jelavich, Barbara, Balkan Tarihi I, Çev. İ. Durdu, H. Koç, G. Koç, Küre Yay., İstanbul 2009.

Jezernik, Bozidar, Vahşi Avrupa, Batı'da Balkan Imajı, Çev. Haşim Koç, Küre Yay., İstanbul, 2006.

Karaer, Nihat, Sultan Abdülaziz'in Avrupa Seyahati ile Osmanlı ve Batı Kamuoyundaki Yankıları, Doktora Tezi, Ankara Üniversitesi, Sosyal Bilimler Enstitüsü, Ankara, 2003.

Köksal, Osman, "Sultan Aziz'in Avrupa Seyahati Dönüşü Münasebetiyle Yapılan Kutlamalar Ve Bir Manzum Tarihçe", Osmangazi Üniversitesi Sosyal Bilimler Dergisi, Cilt: 4 Sayı: 1 Haziran, Eskişehir, 2003, s. 117-134.

Özkan, Ayşe, Miloş'tan Milan'a Sırp Bağımsızlığı (1830-1878), IQ Yay., İstanbul 2011.

Palmer, Alan, Son Üç Yüz Yıl Osmanlı Imparatorluğu(Bir Çöküşün Tarihi), Çev. Belkıs Çorakçı Dişbudak, İş Bankası Yay., İstanbul, 2003.

Quataert, Donald, Osmanlı Imparatorluğu 1700-1922, Çev. Ayşe Berktay, İletişim Yay., İstanbul 2004.

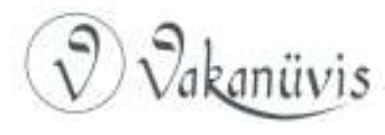


Servante, Alain, "Batılıların Gözünde Türk İmajının Geçirdiği Değişimler, Cehennem Teolojisinden Demokrasi Derslerine", Çev. Serpil Çağlayan, Dünyada Türk Imgesi, Yay. Haz. Özlem Kumrular, Kitap Yayınevi, İstanbul, 2005, ss. 27-85.

Tural, Erkan, "1861 Hersek İsyanı, 1863 Eyalet Teftişleri ve 1864 Vilayet Nizamnâmesi", Çağdaş Yerel Yönetimler, Cilt 13 Sayı 2 Nisan 2004, s. 93-123. 